\title{
The central role of nucleic acids in the pathogenesis of
}

\section{systemic lupus erythematosus [version 1; peer review: 3}

\section{approved]}

\author{
David S. Pisetsky
}

Department of Medicine and Immunology, Duke University Medical Center and Medical Research Service, VA Medical Center, Durham, NC, USA

V1 First published: 03 Apr 2019, 8(F1000 Faculty Rev):368
https://doi.org/10.12688/f1000research.17959.1

Latest published: 03 Apr 2019, 8(F1000 Faculty Rev):368

https://doi.org/10.12688/f1000research.17959.1

\section{Abstract}

Systemic lupus erythematosus (SLE) is a prototypic autoimmune disease whose pathogenesis can be conceptualized by a model based on a central role for immune complexes (ICs) between antinuclear antibodies and nucleic acids. According to this model, ICs can promote pathogenesis by two main mechanisms: deposition in the tissue to incite local inflammation and interaction with cells of the innate immune system to stimulate the production of cytokines, most prominently type 1 interferon. The latter stimulation results from the uptake of DNA and RNA in the form of ICs into cells and subsequent signaling by internal nucleic acid sensors for DNA and RNA. These sensors are likely important for the response to intracellular infection, although they may also be triggered during cell stress or injury by DNA or RNA aberrantly present in the cytoplasm. For IC formation, a source of extracellular DNA and RNA is essential. The current model of SLE posits that cell death is the origin of the nucleic acids in the ICs and that impairment of clearance mechanisms increases the amount of nuclear material in the extracellular space. This model of SLE is important since it points to new approaches to therapy; agents targeting interferon or the interferon receptor are examples of therapeutic approaches derived from this model. Future studies will explore novel biomarkers to monitor the operation of these mechanisms and to elucidate other steps in pathogenesis that can be targeted for therapy.

\section{Keywords}

Lupus, DNA, RNA, antinuclear antibody, interferon, DNase, microparticles

\section{Open Peer Review}

$\begin{array}{rrr}\text { Approval Status } & \checkmark \checkmark \\ 1 & 2 & 3\end{array}$

\section{version 1}

03 Apr 2019

Faculty Reviews are review articles written by the prestigious Members of Faculty Opinions. The articles are commissioned and peer reviewed before publication to ensure that the final, published version is comprehensive and accessible. The reviewers who approved the final version are listed with their names and affiliations.

1. George C. Tsokos, Beth Israel Deaconess Medical Center, Harvard Medical School, Boston, USA

2. Phillip L Cohen, Temple University School of Medicine, Philadelphia, USA

3. Eric Boilard, Centre de Recherche du CHU de Québec-Université Laval, Quebec City, Quebec, Canada

Any comments on the article can be found at the end of the article. 
Corresponding author: David S. Pisetsky (david.pisetsky@duke.edu)

Author roles: Pisetsky DS: Conceptualization, Funding Acquisition, Investigation, Writing - Original Draft Preparation, Writing - Review \& Editing

Competing interests: No competing interests were disclosed.

Grant information: This work was supported by VA Merit Review.

The funders had no role in study design, data collection and analysis, decision to publish, or preparation of the manuscript.

Copyright: @ 2019 Pisetsky DS. This is an open access article distributed under the terms of the Creative Commons Attribution License, which permits unrestricted use, distribution, and reproduction in any medium, provided the original work is properly cited.

How to cite this article: Pisetsky DS. The central role of nucleic acids in the pathogenesis of systemic lupus erythematosus

[version 1; peer review: 3 approved] F1000Research 2019, 8(F1000 Faculty Rev):368 https://doi.org/10.12688/f1000research.17959.1

First published: 03 Apr 2019, 8(F1000 Faculty Rev):368 https://doi.org/10.12688/f1000research.17959.1 


\section{Introduction}

Systemic lupus erythematosus (SLE) is a prototypic systemic autoimmune disease that primarily affects young women and causes highly variable clinical and serological manifestations ${ }^{1,2}$. Clinically, SLE is marked by inflammation and damage of multiple organ systems, including the joints, skin, kidney, nervous system, and blood. Immunologically, SLE is associated with the production of autoantibodies to a wide variety of macromolecules, especially those in the cell nucleus (antinuclear antibodies, or ANAs). The widespread autoreactivity in SLE has suggested a role of more generalized or global immune disturbances in pathogenesis. Indeed, studies on immune cell function and phenotype have identified a multitude of B- and T-cell disturbances that could promote autoreactivity ${ }^{3}$.

An important clinical condition because of its major impact on young women, SLE has been widely studied as a model for immune regulation since its pathogenesis involves the most critical steps for immune tolerance. In tolerance, the recognition of selfantigens is prevented by a host of mechanisms operating in both $\mathrm{B}$ and $\mathrm{T}$ cells. In SLE, tolerance is breached and autoantibody expression occurs, driving inflammatory manifestations. The study of SLE pathogenesis is also important since effective treatment is limited at present and the development of new agents for SLE can provide a setting to gain fundamental new insights into immunosuppression relevant not only for SLE but also for other autoimmune diseases. This review will consider a current model for mechanisms underlying the pathogenesis of SLE and the implications for the development of new biomarkers and treatment.

\section{Model for systemic lupus erythematosus pathogenesis}

SLE can affect many organ systems; individual patients, however, generally show more limited patterns of involvement. Indeed, SLE can vary from a relatively mild condition of skin and joints to a fulminant condition leading to rapidly progressive glomerulonephritis. Although the basis of this heterogeneity is unknown, certain features suggest the operation of some common mechanisms that encompass various patient subsets. Thus, patients with SLE almost always produce characteristic ANAs, and ANA expression is a criterion for disease classification ${ }^{4,5}$. In addition, genome-wide association studies have identified polymorphisms highly associated with SLE. In this construct, a variety of different genes, including some related to ancestry, may predispose patients to autoimmunity, and the array of genes in association with environmental exposures confer heterogeneity ${ }^{6}$.

In recent years, studies of patients with SLE and mouse models of lupus have produced a coherent, even compelling, model of disease to guide investigation and provide a framework for new therapy. This model is based on the proposition that, in SLE, aberrant responses to nucleic acids disrupt immune regulation and, in a genetically susceptible individual, drive ANA production. These ANAs in turn can form immune complexes (ICs) with nucleic acids that have entered the circulation as a consequence of cell death. Disease manifestations result from downstream actions of these ICs which have two distinct roles in disease.
The first role is the deposition in the kidney to induce nephritis, an important determinant of morbidity and mortality. The second (and perhaps unexpected) role derives from the immunological actions of nucleic acids that become manifest when in the form of $\mathrm{ICs}^{7-10}$. Figure 1 illustrates this model.

\section{Role of antinuclear antibodies}

In determining the immunological consequences of ICs containing nucleic acids, ANA specificity is key. In SLE, ANAs target highly conserved nuclear molecules that are present in all cells. These antibodies can be conveniently divided into families on the basis of the nucleic acid content ${ }^{5,11,12}$. The first family is directed to components of the nucleosome and prominently includes anti-DNA. These antibodies bind to both single-stranded and double-stranded DNA and react to determinants present on the phosphodiester backbone ${ }^{13,14}$. In contrast, antibodies to RNAbinding proteins (RBPs) target complexes of RNA and proteins. These complexes are denoted as Sm, RNP, Ro, and La; in all cases, the antibodies bind to the protein and not the $\mathrm{RNA}^{5,12}$.

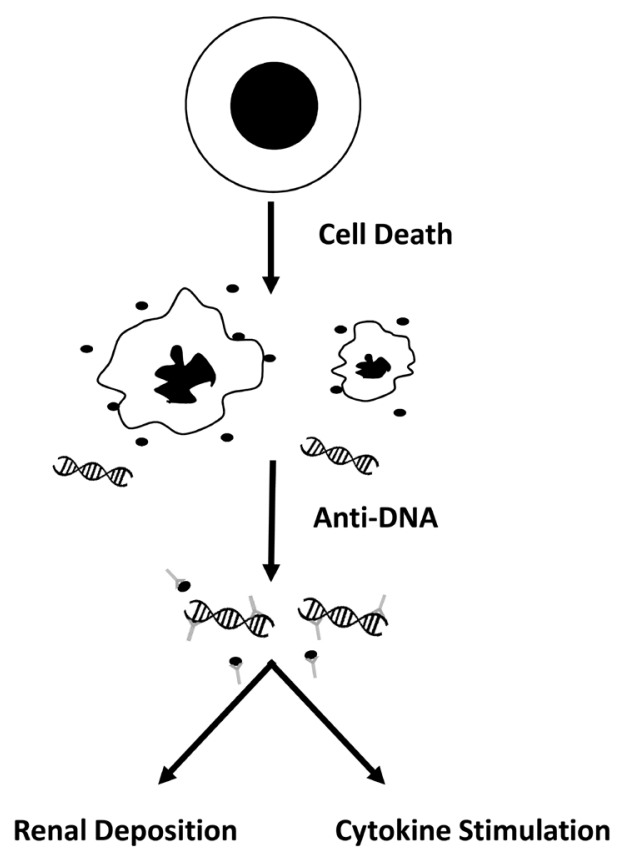

Figure 1. The role of DNA and anti-DNA in the pathogenesis of systemic lupus erythematosus. The figure provides a schema for the pathogenesis of systemic lupus erythematosus. In this model, as cells die by apoptosis, the nucleus collapses and fragments, and the cell body shrinks, producing apoptotic bodies as well as microparticles (filled circles) which contain DNA. In addition, the cell releases DNA in a free form; in the free form, DNA may be associated with histones to form the nucleosome. DNA in microparticles as well as free DNA can bind to anti-DNA antibodies to form immune complexes. These immune complexes then can deposit in the kidney to induce nephritis or can stimulate cytokine production following uptake by plasmacytoid dendritic cells. Thus, DNA can start on the inside of one cell, translocate to the outside in the blood, and then go back into the inside of another cell. A similar mechanism pertains to anti-RNA-binding protein (anti-RBP) antibodies, although, for these specificities, antibodies bind to the protein rather than the RNA. 
Despite differences in the structure of their antigens and pattern of expression, anti-DNA and anti-Sm are both serological criteria for SLE.

The screening for ANAs has long been a central element in patient evaluation, although the role of specific ANAs in disease pathogenesis has until now been less certain. Anti-DNA has been the exception since, in SLE, there is clear evidence that ICs composed of anti-DNA antibodies deposit in the kidney; furthermore, in many patients, levels of anti-DNA rise and fall with disease activity, especially nephritis activity. In this situation, depression in complement levels can occur concordantly, pointing to the presence of ICs. Unlike those of anti-DNA, levels of anti-RBPs are frequently static during the course of disease, showing little change with disease activity. As such, it has been difficult to relate anti-RBPs to either disease activity or particular clinical manifestations ${ }^{5,15}$.

Recent studies, however, have provided a new picture of the role of ANAs and revealed a mechanism by which ICs with either anti-DNA or anti-RBPs can induce inflammation. This mechanism involves the stimulation of cells of the innate immune system, especially plasmacytoid dendritic cells, to produce type 1 interferon and other pro-inflammatory mediators. Type 1 interferons are an ensemble of cytokines that are pleiotropic in action and can promote many of the clinical and immunological features of SLE. With current technology, the presence of type 1 interferon is usually assessed by the analysis of the pattern of gene expression in peripheral blood cells rather than the immunochemical assay of interferon itself ${ }^{16-18}$. An "interferon signature" occurs prominently in many patients with SLE and has spurred the development of therapies that target either members of the interferon family or the interferon receptor ${ }^{19-22}$. In this regard, levels of interferon may relate to polymorphisms in genes encoding signaling proteins involved in transcriptional control of interferon as well as a complex interplay between the nature of the ICs and regulations of interferon expression ${ }^{23-25}$.

\section{Nucleic acid sensors}

The reason that ICs with DNA and RNA can drive cytokine production relates to the intrinsic immunological properties of nucleic acids. Indeed, DNA and RNA both have potent immunostimulatory activity; depending on the source, DNA and RNA can serve as PAMPs (pathogen-associated molecular patterns) or DAMPs (damage- or death-associated molecular patterns) to activate innate immunity via internal nucleic acid sensors. These sensors include Toll-like receptor (TLR) 3, 7/8, and 9 as well as non-TLR sensors ${ }^{26}$. Non-TLRs include the nucleotidebinding and oligomerization domain (NOD) receptors (or NLRs) and the retinoic acid-inducible gene 1 (RIG-1)-like receptors (RLRs). Importantly, these sensors reside on the inside of cells in contrast to other sensors or pattern recognition receptors (PRRs) which are present on the outer cell membrane (for example, TLR 4 for lipopolysaccharide, or LPS).

As shown in in vivo and in vitro systems, internal nucleic acid sensors play a key role in host defense against intracellular infection by viruses and bacteria. Furthermore, internal sensors can mediate the response to events such as oxidative stress. In these situations, nucleic acids translocate from their usual location or compartment and gain access to internal sensors to activate inflammation. Among organelles, mitochondria represent an abundant source of DNA that can access internal sensors. Compared with nuclear DNA, mitochondrial DNA is more potent immunologically because of its base sequences and content of oxidized bases. Perhaps reflecting the origin of mitochondria as symbiotic bacteria, mitochondrial DNA resembles bacterial DNA in its content of $\mathrm{CpG}$ motifs (cytosine guanosine dinucleotides) which confer PAMP activity on foreign $\mathrm{DNA}^{27,28}$. Table 1 lists determinants of the immune properties of DNA.

While RNA is present abundantly in the cytoplasm of cells, stimulation of RNA sensors occurs with particular forms of these molecules or the interaction of sensors with RNA in particular locations $^{29}$. Thus, stimulation of the RIG-1 sensor occurs with RNA from certain viruses that display characteristic structural features at the $5^{\prime}$ end of the RNA molecule. For the MDA5 sensor, stimulation may depend on the length and structure of the RNA molecule, including long stretches with base pairs ${ }^{30}$. For TLRs recognizing RNA, the interaction occurs in an endosomal compartment, although transport systems can allow movement of RNA from the endosomal compartment to the cytoplasm for interaction with RLRs ${ }^{31}$. Another source of stimulatory RNA is mitochondrial RNA that has entered the cytoplasm because of a deficiency of enzymes involved in degradation ${ }^{32}$.

Among internal sensing systems, the cyclic GMP-AMP synthase-stimulator of interferon genes (cGAS-STING) pathway can mediate the response to cytosolic DNA and has attracted interest as a target of therapy in diseases such as cancer and autoimmunity $^{33,34}$. In this response, the protein cGAS binds to DNA to catalyze the reaction of GTP and ATP to form cyclic GMP-AMP (cGAMP). cGAMP in turn binds to STING that leads to the phosphorylation of IRF3, which induces the transcription of pro-inflammatory genes. Although this pathway may be important in host defense to DNA viruses, it can be activated during cellular stress when DNA from the nucleus or mitochondria translocates to the cytoplasm. Agents targeting the cGASSTING system are in development as novel therapies for SLE ${ }^{35}$.

Along with systems that sense cytoplasmic nucleic acids are systems that degrade DNA and RNA that have gained access to

Table 1. Determinants of immune properties of DNA.

Sequence
Size
Backbone structure
Oxidation state
Source (that is, nucleus versus mitochondria)
Protein binding
Presence in an immune complex
Intracellular location

Sequence

Size 
the cytoplasm. These putatively protective systems include nucleases such as TREX, which is a $3^{\prime}$ exonuclease that can degrade double-stranded DNA. In humans, mutations in TREX are associated with Aicardi-Goutières syndrome (AGS); AGS has some features of SLE as well as prominent production of type 1 interferon, especially in the central nervous system ${ }^{36,37}$. Mice lacking TREX also develop features of SLE, including myocarditis, suggesting that an increase in intracellular DNA can drive disease by triggering internal DNA sensors. This possibility is supported by observations that mice with a double knockout of TREX and cGAS are protected from autoantibody production as well as tissue inflammation ${ }^{38,39}$.

Mutations in internal nucleic acid sensors and nucleases are rare causes of SLE in humans, although these conditions suggest a mechanism by which nucleic acids can drive autoreactivity via the internal receptors. In this schema, ANAs are critical effectors since they can form ICs that transport DNA and RNA into cells of the innate immune system. Once inside the cell, nucleic acids can interact with sensing systems to stimulate interferon and other cytokines ${ }^{40-43}$. Since there are sensors for DNA and RNA, ICs from both anti-DNA and anti-RBP antibodies can activate this pathway, accounting for the association of these ANAs with the interferon signature. Importantly, the interferon signature does not vary much with disease activity, suggesting that anti-RBP antibodies may be prominent players in this response because of their high titers and chronic expression $^{4,15,44-46}$.

Although ANAs are an important sign of autoimmunity in lupus, their presence may not be sufficient to induce disease manifestations. Indeed, ANA expression can predate clinical disease manifestations by many years in a state called pre-autoimmunity ${ }^{47-49}$. Other elements must be present to convert the serological manifestations into clinical manifestations. Among these elements, self-antigen, present in quantities sufficient to allow IC formation, may be key. In this conceptualization, the development of disease is a two-step process. The first step is ANA production. This step may occur in genetically susceptible individuals who, following an infection, for example, produce a cross-reactive antibody that binds both a foreign and a self-antigen; genetically determined disturbances in B- and T-cell regulation may underlie a tendency to produce cross-reactive antibodies and breach tolerance.

\section{Generation of extracellular nuclear antigens}

While ANAs may be pathological (that is, aberrantly produced), alone these antibodies may not be pathogenic (that is, cause specific disease manifestations). In IC disease, pathogenicity is multifactorial and depends on the immunochemical properties of antibodies such as avidity and fine specificity as well as the availability of self-antigen. Although, by definition, self-antigen is always present in the organism, it may not be present in sufficient concentrations or locations to form ICs to induce nephritis or drive cytokine production. The most likely source of self-antigen for IC formation is cell death since every day a large number of cells die and can release their contents.
Since DNA and other endogenous molecules (DAMPs) arising during death are potentially immunostimulatory, dying cells and their "dangerous" contents must be removed in a safe or silent way. In addition to the role of phagocytosis, clearance depends on serum proteins such as complement, DNases, and RNases to manage the load of nucleic acids that could fill the blood ${ }^{50}$. Interestingly, deficiency of $\mathrm{C} 1 \mathrm{q}$, a complement component important for clearance, represents a single gene model for SLE, suggesting that increased levels of both intracellular and extracellular nucleic acids are pathogenic.

As now recognized, cells die by a variety of biochemically and morphologically defined forms of death which depend on the nature of the inducing stimulus and the cell type. Among these death forms, apoptosis occurs in both physiological and pathological settings and involves the systematic disassembly of the cell mediated by enzymes known as caspases. During apoptosis, DNA along with other nuclear molecules is cleaved and rearranged, possibly to reduce immune activity. Furthermore, as apoptosis proceeds, nuclear molecules can translocate to the cell membrane to enter blebs. Although the function of blebs is not well understood, the localization of nuclear antigens in these structures may alter their immunological properties. Given the frequency of cell death in the body, apoptosis is often considered the death form that creates extracellular DNA and RNA $^{51,52}$.

Apoptosis is not the only death form that can release DNA, however, since necrosis, a form of accidental cell death, can also increase levels of extracellular DNA presumably because of cell lysis and destruction that characterize this process. In contrast to necrosis, necroptosis is a form of programmed cell death that can be induced by a variety of agents and involves the activity of enzymes known as the receptor-interacting protein kinases. Necroptosis can occur with the inhibition of caspases during stimulation by TLR agonists, suggesting complex regulatory interactions that can lead to death or activation ${ }^{53}$. Importantly, cells undergoing necroptosis can release nuclear molecules and other cellular constituents with immune activity ${ }^{54,55}$.

A particularly novel death process that occurs primarily with neutrophils is termed NETosis ${ }^{56,57}$. NETosis can be induced by a variety of stimuli and is associated with the breakdown of the nuclear membrane, the mixing of DNA with the granule enzymes, and the extracellular release of a mesh-like structure known as a NET (neutrophil extracellular trap). A NET can entrap bacteria for killing by the protein components such as myeloperoxidase and histones; a NET can also contain mitochondrial DNA. In addition to having an anti-bacterial function, a NET can damage endothelium and serve as a source of DNA for IC formation ${ }^{58}$. Thus, an increase in the concentration of DNA in the blood can occur by a number of mechanisms that operate in SLE.

Although DNA in the blood can exist in a free form (albeit attached to histones), it may also be present as a component of microparticles (MPs). MPs are extracellular vesicles that can be released from activated as well as dead and dying cells, possibly 
representing blebs that have detached from cells undergoing apoptosis ${ }^{59}$. These subcellular structures are approximately 0.1 to 1.0 microns in diameter and contain a range of membrane, cytoplasmic, and nuclear molecules, including DNA (Table 2). Importantly, the DNA in MPs can be bound by anti-DNA antibodies either because it resides on the particle surface or because the particle is sufficiently porous to allow the entry of antibodies into its interior. As shown with murine monoclonal anti-nucleosomal antibodies, only some anti-DNA can bind particles, suggesting that the display of DNA epitopes may be selective $^{60,61}$.

Studies using flow cytometry demonstrate that the blood of patients with SLE contains increased numbers of particles with bound IgG as well as complement. Furthermore, the levels of the IgG-positive particles may be related to levels of anti-DNA as well as disease activity ${ }^{62-66}$. There is also evidence that ICs containing particles can deposit in the renal glomerulus, as shown by histopathologic staining of kidney biopsies for the galectin-3-binding protein, a component of $\mathrm{MPs}^{67}$. Together, these findings point to MPs as an important source of DNA for IC formation. Although ICs have long been considered an essential element in disease pathogenesis, their physical identification using conventional approaches appropriate for analyzing soluble complexes has, in fact, been difficult. The formation of ICs based on a particle structure would be fundamentally different from that of a complex with a soluble antigen and would require other analytic techniques for identification and quantification, including the use of plasma.

As discussed above, the amount of DNA in the blood depends on processes that increase its concentration (that is, cell death) and the processes that decrease its concentration (that is, nucleases). Although the enzyme DNase 1 can digest DNA, studies on a related DNase called DNase 1-like 3 (DNase 1L3) have provided a new perspective on the degradative process ${ }^{68,69}$. DNase 1L3 differs in its specificity for DNA from DNase 1. Whereas DNase 1 degrades free DNA, DNase 1L3 degrades

\section{Table 2. Properties of microparticles.}

Membrane-bound vesicles

0.1 to 1.0 microns

Ensemble of nuclear, cytoplasmic, and membrane molecules Source of extracellular nucleic acids

Formation of immune complexes with antinuclear antibodies
DNA in the form of nucleosomes, likely an important form of extracellular DNA. Patients with mutations in DNase 1L3 present with a vasculitis-like condition, whereas mice with a knockout of the gene for DNase 1L3 develop a lupus-like illness with antiDNA production and a dramatic increase in DNA associated with $\mathrm{MPs}^{70-74}$. These observations provide evidence for the relevance of particles as a source of extracellular DNA for IC formation and suggest the use of MP-ICs as biomarkers.

\section{Unanswered questions}

This model for pathogenesis of SLE is very plausible and has considerable support from experimental data. Nevertheless, many aspects are unknown. Salient issues that can be the subject of future study concern the actual form of DNA (and other nuclear molecules) in the extracellular milieu, the specificity of ANAs that can form ICs, and the detailed mechanisms for the trafficking of DNA and RNA molecules that are introduced into the inside of cells in the form of ICs. In terms of host defense, events on the inside of cells are becoming as important as events outside of cells. Understanding of events in SLE will therefore need fundamental investigation to elucidate the role of immune signaling by cytoplasmic nucleic acids in the context of infection.

\section{Conclusions}

Historically, SLE has been conceptualized as a disease of ICs composed of ANAs and their cognate nuclear antigens. Although this basic schema still pertains, recent studies have provided a new and unexpected picture of the basic triad of autoantigens, autoantibodies, and ICs by demonstrating that (1) nucleic acids are immunologically active, (2) nucleic acids can trigger receptors that are part of an internal host defense system, and (3) ICs may involve large antigenic structures in which DNA and RNA are embedded in particles. Furthermore, recent studies have delineated systems that regulate the levels of both intra- and extracellular nucleic acids and thereby their ability to drive inflammation. In this model, DNA or RNA can leave one cell and, via ICs, enter another to trigger an internal receptor. Future studies will translate this basic information into the creation of new biomarkers and the development of new therapies that can target more specifically the pathways by which nucleic acids initiate and sustain autoreactivity.

Grant information

This work was supported by VA Merit Review.

The funders had no role in study design, data collection and analysis, decision to publish, or preparation of the manuscript.
1. Lisnevskaia L, Murphy G, Isenberg D: Systemic lupus erythematosus. Lancet. 2014; 384(9957): 1878-88. PubMed Abstract | Publisher Full Text

2. Kaul A, Gordon C, Crow MK, et al:: Systemic lupus erythematosus. Nat Rev Dis Primers. 2016; 2: 16039. PubMed Abstract | Publisher Full Text
3. Tsokos GC, Lo MS, Costa Reis P, et al:: New insights into the immunopathogenesis of systemic lupus erythematosus. Nat Rev Rheumatol. 2016; 12(12): 716-30. PubMed Abstract | Publisher Full Text

4. Ippolito A, Wallace DJ, Gladman D, et al.: Autoantibodies in systemic lupus erythematosus: comparison of historical and current assessment of 
seropositivity. Lupus. 2011; 20(3): 250-5 PubMed Abstract | Publisher Full Text

5. Pisetsky DS: Antinuclear antibody testing - misunderstood or misbegotten? Nat Rev Rheumatol. 2017; 13(8): 495-502. PubMed Abstract | Publisher Full Text

6. F Goulielmos GN, Zervou MI, Vazgiourakis VM, et al.: The genetics and molecular pathogenesis of systemic lupus erythematosus (SLE) in populations of different ancestry. Gene. 2018; 668: 59-72. PubMed Abstract | Publisher Full Text | F1000 Recommendation

7. Shrivastav M, Niewold TB: Nucleic Acid sensors and type I interferon production in systemic lupus erythematosus. Front Immunol. 2013; 4: 319. PubMed Abstract | Publisher Full Text | Free Full Text

8. Sharma S, Fitzgerald KA, Cancro MP, et al:: Nucleic Acid-Sensing Receptors: Rheostats of Autoimmunity and Autoinflammation. J Immunol. 2015; 195(8): 3507-12.

PubMed Abstract | Publisher Full Text | Free Full Text

9. Barrat FJ, Elkon KB, Fitzgerald KA: Importance of Nucleic Acid Recognition in Inflammation and Autoimmunity. Annu Rev Med. 2016; 67: 323-36. PubMed Abstract | Publisher Full Text

10. Eloranta ML, Rönnblom L: Cause and consequences of the activated type $\mathrm{I}$ interferon system in SLE. J Mol Med (Berl). 2016; 94(10): 1103-10. PubMed Abstract | Publisher Full Text | Free Full Text

11. Agmon-Levin N, Damoiseaux J, Kallenberg C, et al.: International recommendations for the assessment of autoantibodies to cellular antigens referred to as anti-nuclear antibodies. Ann Rheum Dis. 2014; 73(1): 17-23. PubMed Abstract | Publisher Full Text

12. Ching $\mathrm{KH}$, Burbelo PD, Tipton $\mathrm{C}$, et al.: Two major autoantibody clusters in systemic lupus erythematosus. PLoS One. 2012; 7(2): e32001. PubMed Abstract | Publisher Full Text | Free Full Text

13. Rekvig OP: The anti-DNA antibody: origin and impact, dogmas and controversies. Nat Rev Rheumatol. 2015; 11(9): 530-40. PubMed Abstract | Publisher Full Text

14. Pisetsky DS: Anti-DNA antibodies--quintessential biomarkers of SLE. Nat Rev Rheumatol. 2016; 12(2): 102-10.

PubMed Abstract | Publisher Full Text

15. McCarty GA, Rice JR, Bembe ML, et al.: Independent expression of autoantibodies in systemic lupus erythematosus. $J$ Rheumatol. 1982; 9(5): $691-5$.

PubMed Abstract

16. Crow MK: Type I interferon in the pathogenesis of lupus. J Immunol. 2014; 192(12): 5459-68.

PubMed Abstract | Publisher Full Text | Free Full Text

17. Muskardin TLW, Niewold TB: Type I interferon in rheumatic diseases. Nat Rev Rheumatol. 2018; 14(4): 214-28.

PubMed Abstract | Publisher Full Text

18. Chiche L, Jourde-Chiche N, Whalen E, et al:: Modular transcriptional repertoire analyses of adults with systemic lupus erythematosus reveal distinct type I and type II interferon signatures. Arthritis Rheumatol. 2014; 66(6): 1583-95. PubMed Abstract | Publisher Full Text | Free Full Text

19. Crow MK, Olferiev M, Kirou KA: Targeting of type I interferon in systemic autoimmune diseases. Transl Res. 2015; 165(2): 296-305. PubMed Abstract | Publisher Full Text | Free Full Text

20. F Banchereau R, Hong S, Cantarel B, et al:: Personalized Immunomonitoring Uncovers Molecular Networks that Stratify Lupus Patients. Cell. 2016; 165(3): $551-65$

PubMed Abstract | Publisher Full Text | Free Full Text | F1000 Recommendation

21. F Khamashta M, Merrill JT, Werth VP, et al:: Sifalimumab, an anti-interferon- 0 monoclonal antibody, in moderate to severe systemic lupus erythematosus: a randomised, double-blind, placebo-controlled study. Ann Rheum Dis. 2016; 75(11): 1909-16.

PubMed Abstract | Publisher Full Text | Free Full Text | F1000 Recommendation

22. F Furie R, Khamashta M, Merrill JT, et al.: Anifrolumab, an Anti-Interferon$\alpha$ Receptor Monoclonal Antibody, in Moderate-to-Severe Systemic Lupus Erythematosus. Arthritis Rheumatol. 2017; 69(2): 376-86. PubMed Abstract | Publisher Full Text | Free Full Text | F1000 Recommendation

23. Niewold TB, Hua J, Lehman TJA, et al.: High serum IFN-alpha activity is a heritable risk factor for systemic lupus erythematosus. Genes Immun. 2007; 8(6): 492-502.

PubMed Abstract | Publisher Full Text | Free Full Text

24. F Niewold TB, Kelly JA, Kariuki SN, et al: IRF5 haplotypes demonstrate diverse serological associations which predict serum interferon alpha activity and explain the majority of the genetic association with systemic lupus erythematosus. Ann Rheum Dis. 2012; 71(3): 463-8.

PubMed Abstract | Publisher Full Text | Free Full Text | F1000 Recommendation

25. Ko K, Koldobskaya Y, Rosenzweig E, et al:: Activation of the Interferon Pathway is Dependent Upon Autoantibodies in African-American SLE Patients, but Not in European-American SLE Patients. Front Immunol. 2013; 4: 309.

PubMed Abstract | Publisher Full Text | Free Full Text

26. Lenert $P$ : Nucleic acid sensing receptors in systemic lupus erythematosus: development of novel DNA- and/or RNA-like analogues for treating lupus. Clin Exp Immunol. 2010; 161(2): 208-22.

PubMed Abstract | Publisher Full Text | Free Full Text
27. F West AP, Shadel GS: Mitochondrial DNA in innate immune responses and inflammatory pathology. Nat Rev Immunol. 2017; 17(6): 363-75. PubMed Abstract | Publisher Full Text | F1000 Recommendation

28. F Meyer A, Laverny G, Bernardi L, et al.: Mitochondria: An Organelle of Bacterial Origin Controlling Inflammation. Front Immunol. 2018; 9: 536. PubMed Abstract | Publisher Full Text | Free Full Text | F1000 Recommendation

29. F Tatematsu M, Funami K, Seya T, et al.: Extracellular RNA Sensing by Pattern Recognition Receptors. J Innate Immun. 2018; 10(5-6): 398-406. PubMed Abstract | Publisher Full Text | F1000 Recommendation

30. F Dias Junior AG, Sampaio NG, Rehwinkel J: A Balancing Act: MDA5 in Antiviral Immunity and Autoinflammation. Trends Microbiol. 2019; 27(1): 75-85. PubMed Abstract | Publisher Full Text | Free Full Text | F1000 Recommendation

31. F Nguyen TA, Smith BRC, Tate MD, et al:: SIDT2 Transports Extracellular dsRNA into the Cytoplasm for Innate Immune Recognition. Immunity. 2017; 47(3): 498-509.e6.

PubMed Abstract | Publisher Full Text | Free Full Text | F1000 Recommendation

32. F Dhir A, Dhir S, Borowski LS, et al.: Mitochondrial double-stranded RNA triggers antiviral signalling in humans. Nature. 2018; 560(7717): 238-42. PubMed Abstract | Publisher Full Text | F1000 Recommendation

33. F Sun L, Wu J, Du F, et al:: Cyclic GMP-AMP synthase is a cytosolic DNA sensor that activates the type I interferon pathway. Science. 2013; 339(6121): 786-91.

PubMed Abstract | Publisher Full Text | Free Full Text | F1000 Recommendation

34. F Li T, Chen ZJ: The cGAS-cGAMP-STING pathway connects DNA damage to inflammation, senescence, and cancer. J Exp Med. 2018; 215(5): 1287-99. PubMed Abstract | Publisher Full Text | Free Full Text | F1000 Recommendation

35. F An J, Woodward JJ, Lai W, et al:: Inhibition of Cyclic GMP-AMP Synthase Using a Novel Antimalarial Drug Derivative in Trex1-Deficient Mice. Arthritis Rheumatol. 2018; 70(11): 1807-19.

PubMed Abstract | Publisher Full Text | F1000 Recommendation

36. Crow YJ, Manel N: Aicardi-Goutières syndrome and the type I interferonopathies. Nat Rev Immunol. 2015; 15(7): 429-40. PubMed Abstract | Publisher Full Text

37. Grieves JL, Fye JM, Harvey S, et al:: Exonuclease TREX1 degrades doublestranded DNA to prevent spontaneous lupus-like inflammatory disease. Proc Natl Acad Sci U S A. 2015; 112(16): 5117-22.

PubMed Abstract | Publisher Full Text | Free Full Text

38. Ablasser A, Hemmerling I, Schmid-Burgk JL, et al:: TREX1 deficiency triggers cell-autonomous immunity in a cGAS-dependent manner. J Immunol. 2014; 192(12): 5993-7.

PubMed Abstract | Publisher Full Text

39. Gray EE, Treuting PM, Woodward JJ, et al: Cutting Edge: cGAS Is Required fo Lethal Autoimmune Disease in the Trex1-Deficient Mouse Model of AicardiGoutières Syndrome. J Immunol. 2015; 195(5): 1939-43. PubMed Abstract | Publisher Full Text | Free Full Text

40. Vallin H, Perers A, Alm GV, et al:: Anti-double-stranded DNA antibodies and immunostimulatory plasmid DNA in combination mimic the endogenous IFN-alpha inducer in systemic lupus erythematosus. J Immunol. 1999; 163(11): 6306-13.

PubMed Abstract

41. Lövgren T, Eloranta ML, Båve U, et al: Induction of interferon-alpha production in plasmacytoid dendritic cells by immune complexes containing nucleic acid released by necrotic or late apoptotic cells and lupus IgG. Arthritis Rheum. 2004; 50(6): 1861-72

PubMed Abstract | Publisher Full Tex

42. Kirou KA, Lee C, George S, et al:: Activation of the interferon-alpha pathway identifies a subgroup of systemic lupus erythematosus patients with distinct serologic features and active disease. Arthritis Rheum. 2005; 52(5): 1491-503. PubMed Abstract | Publisher Full Text

43. Weckerle CE, Franek BS, Kelly JA, et al: Network analysis of associations between serum interferon- $\alpha$ activity, autoantibodies, and clinical features in systemic lupus erythematosus. Arthritis Rheum. 2011; 63(4): 1044-53. PubMed Abstract | Publisher Full Text | Free Full Text

44. Landolt-Marticorena C, Bonventi G, Lubovich A, et al:: Lack of association between the interferon-alpha signature and longitudinal changes in disease activity in systemic lupus erythematosus. Ann Rheum Dis. 2009; 68(9): 1440-6. PubMed Abstract | Publisher Full Text

45. Petri $\mathrm{M}$, Singh $\mathrm{S}$, Tesfasyone $\mathrm{H}$, et al.: Longitudinal expression of type I interferon responsive genes in systemic lupus erythematosus. Lupus. 2009; 18(11): 980-9. PubMed Abstract | Publisher Full Text | Free Full Text

46. F Petri M, Fu W, Ranger A, et al:: Association between changes in gene signatures expression and disease activity among patients with systemic lupus erythematosus. BMC Med Genomics. 2019; 12(1): 4. PubMed Abstract | Publisher Full Text | Free Full Text | F1000 Recommendation Arbuckle MR, McClain MT, Rubertone MV, et al:: Development of autoantibodies before the clinical onset of systemic lupus erythematosus. N Engl J Med. 2003; 349(16): 1526-33

PubMed Abstract | Publisher Full Tex

48. Olsen NJ, Li QZ, Quan J, et al.: Autoantibody profiling to follow evolution of 
lupus syndromes. Arthritis Res Ther. 2012; 14(4): R174 PubMed Abstract | Publisher Full Text | Free Full Text

49. Olsen NJ, Karp DR: Autoantibodies and SLE: the threshold for disease. Nat Rev Rheumatol. 2014; 10(3): 181-6.

PubMed Abstract | Publisher Full Text

50. Mahajan A, Herrmann M, Muñoz LE: Clearance Deficiency and Cell Death Pathways: A Model for the Pathogenesis of SLE. Front Immunol. 2016; 7: 35. PubMed Abstract | Publisher Full Text | Free Full Text

51. F Mistry P, Kaplan MJ: Cell death in the pathogenesis of systemic lupus erythematosus and lupus nephritis. Clin Immunol. 2017; 185: 59-73. PubMed Abstract | Publisher Full Text | Free Full Text | F1000 Recommendation

52. F Elkon KB: Review: Cell Death, Nucleic Acids, and Immunity: Inflammation Beyond the Grave. Arthritis Rheumatol. 2018; 70(6): 805-16. PubMed Abstract | Publisher Full Text | Free Full Text | F1000 Recommendation

53. Kaczmarek A, Vandenabeele P, Krysko DV: Necroptosis: the release of damageassociated molecular patterns and its physiological relevance. Immunity. 2013, 38(2): 209-23.

PubMed Abstract | Publisher Full Text

54. F Murai S, Yamaguchi Y, Shirasaki Y, et al:: A FRET biosensor for necroptosis uncovers two different modes of the release of DAMPs. Nat Commun. 2018; 9(1): 4457.

PubMed Abstract | Publisher Full Text | Free Full Text | F1000 Recommendation

55. Spencer DM, Dye JR, Piantadosi CA, et al. The release of microparticles and mitochondria from RAW 264.7 murine macrophage cells undergoing necroptotic cell death in vitro. Exp Cell Res. 2018; 363(2): 151-9. PubMed Abstract | Publisher Full Text

56. Gupta S, Kaplan MJ: The role of neutrophils and NETosis in autoimmune and renal diseases. Nat Rev Nephrol. 2016; 12(7): 402-13. PubMed Abstract | Publisher Full Text | Free Full Text

57. F Apel F, Zychlinsky A, Kenny EF: The role of neutrophil extracellular traps in rheumatic diseases. Nat Rev Rheumatol. 2018; 14(8): 467-75 PubMed Abstract | Publisher Full Text | F1000 Recommendation

58. F Carmona-Rivera C, Zhao W, Yalavarthi S, et al:: Neutrophil extracellular traps induce endothelial dysfunction in systemic lupus erythematosus through the activation of matrix metalloproteinase-2. Ann Rheum Dis. 2015; 74(7): 1417-24.

PubMed Abstract | Publisher Full Text | Free Full Text | F1000 Recommendation

59. Mobarrez F, Svenungsson E, Pisetsky DS: Microparticles as autoantigens in systemic lupus erythematosus. Eur J Clin Invest. 2018; 48(12): e13010. PubMed Abstract | Publisher Full Text

60. Ullal AJ, Reich CF 3rd, Clowse M, et al.: Microparticles as antigenic targets of antibodies to DNA and nucleosomes in systemic lupus erythematosus. $J$ Autoimmun. 2011; 36(3-4): 173-80. PubMed Abstract | Publisher Full Text

61. Ullal AJ, Marion TN, Pisetsky DS: The role of antigen specificity in the bindin of murine monoclonal anti-DNA antibodies to microparticles from apoptotic cells. Clin Immunol. 2014; 154(2): 178-87.

PubMed Abstract | Publisher Full Text | Free Full Text

62. Nielsen CT, Østergaard O, Stener L, et al:: Increased IgG on cell-derived plasma microparticles in systemic lupus erythematosus is associated with autoantibodies and complement activation. Arthritis Rheum. 2012; 64(4):

1227-36

PubMed Abstract | Publisher Full Text

63. Fortin PR, Cloutier N, Bissonnette V, et al.: Distinct Subtypes of Microparticle containing Immune Complexes Are Associated with Disease Activity, Damage, and Carotid Intima-media Thickness in Systemic Lupus Erythematosus. J Rheumatol. 2016; 43(11): 2019-25.

PubMed Abstract | Publisher Full Text

64. Mobarrez F, Vikerfors A, Gustafsson JT, et al:: Microparticles in the blood of patients with systemic lupus erythematosus (SLE): phenotypic characterization and clinical associations. Sci Rep. 2016; 6: 36025 PubMed Abstract | Publisher Full Text | Free Full Text

65. F López P, Rodríguez-Carrio J, Martínez-Zapico A, et al.: Circulating microparticle subpopulations in systemic lupus erythematosus are affected by disease activity. Int J Cardiol. 2017; 236: 138-44. PubMed Abstract | Publisher Full Text | F1000 Recommendation

66. F Østergaard O, Nielsen CT, Tanassi JT, et al.: Distinct proteome pathology of circulating microparticles in systemic lupus erythematosus. Clin Proteomics. 2017; 14: 23.

PubMed Abstract | Publisher Full Text | Free Full Text | F1000 Recommendation

67. Nielsen $\mathrm{CT}$, Østergaard O, Rekvig OP, et al:: Galectin-3 binding protein links circulating microparticles with electron dense glomerular deposits in lupus nephritis. Lupus. 2015; 24(11): 1150-60. PubMed Abstract | Publisher Full Text

68. F Keyel PA: Dnases in health and disease. Dev Biol. 2017; 429(1): 1-11. PubMed Abstract | Publisher Full Text | F1000 Recommendation

69. F Soni C, Reizis B: DNA as a self-antigen: nature and regulation. Curr Opin Immunol. 2018; 55: 31-7.

PubMed Abstract | Publisher Full Text | Free Full Text | F1000 Recommendation

70. Al-Mayouf SM, Sunker A, Abdwani R, et al:: Loss-of-function variant in DNASE1L3 causes a familial form of systemic lupus erythematosus. Nat Genet. 2011; 43(12): 1186-8.

PubMed Abstract | Publisher Full Text

71. Özçakar ZB, Foster J 2nd, Diaz-Horta O, et al.: DNASE1L3 mutations in hypocomplementemic urticarial vasculitis syndrome. Arthritis Rheum. 2013; 65(8): 2183-9.

PubMed Abstract | Publisher Full Text

72. F Sisirak V, Sally B, D'Agati V, et al.: Digestion of Chromatin in Apoptotic Cell Microparticles Prevents Autoimmunity. Cell. 2016; 166(1): 88-101. PubMed Abstract | Publisher Full Text | Free Full Text | F1000 Recommendation

73. $\mathrm{F}$ Carbonella A, Mancano G, Gremese E, et al:: An autosomal recessive DNASE1L3-related autoimmune disease with unusual clinical presentation mimicking systemic lupus erythematosus. Lupus. 2017; 26(7): 768-72. PubMed Abstract | Publisher Full Text | F1000 Recommendation

74. F Weisenburger T, von Neubeck B, Schneider A, et al.: Epistatic Interactions Between Mutations of Deoxyribonuclease 1-Like 3 and the Inhibitory Fc Gamma Receptor IIB Result in Very Early and Massive Autoantibodies Against Double-Stranded DNA. Front Immunol. 2018; 9: 1551.

PubMed Abstract | Publisher Full Text | Free Full Text | F1000 Recommendation 


\section{Open Peer Review}

\section{Current Peer Review Status:}

\section{Editorial Note on the Review Process}

Faculty Reviews are review articles written by the prestigious Members of Faculty Opinions. The articles are commissioned and peer reviewed before publication to ensure that the final, published version is comprehensive and accessible. The reviewers who approved the final version are listed with their names and affiliations.

\section{The reviewers who approved this article are:}

\section{Version 1}

\section{Eric Boilard}

Department of Infectious Diseases and Immunity, Centre de Recherche du CHU de Québec-Université Laval, Quebec City, Quebec, Canada

Competing Interests: No competing interests were disclosed.

\section{Phillip L Cohen}

Temple Autoimmunity Center, Temple University School of Medicine, Philadelphia, PA, USA

Competing Interests: No competing interests were disclosed.

\section{George C. Tsokos}

Division of Rheumatology and Clinical Immunology, Department of Medicine, Beth Israel Deaconess Medical Center, Harvard Medical School, Boston, MA, USA

Competing Interests: No competing interests were disclosed.

The benefits of publishing with F1000Research:

- Your article is published within days, with no editorial bias

- You can publish traditional articles, null/negative results, case reports, data notes and more

- The peer review process is transparent and collaborative

- Your article is indexed in PubMed after passing peer review

- Dedicated customer support at every stage

For pre-submission enquiries, contact research@f1000.com 